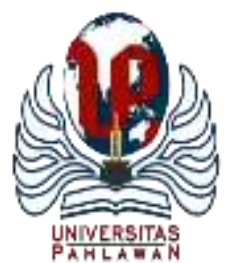

Edukatif : Jurnal Ilmu Pendidikan Volume 3 Nomor 6 Tahun 2021 Halm 4407 - 4414 EDUKATIF: JURNAL ILMU PENDIDIKAN

Research \& Learning in Education

https:/ledukatif.org/index.php/edukatif/index

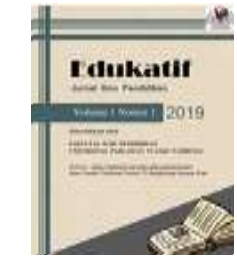

\title{
Pembelajaran Berbasis Daring pada Masa Pandemi Covid-19 di Iisbud Sarea: Problematika, Pemecahan Masalah, dan Harapan
}

\author{
Sri Wahyu Hidayati ${ }^{1 凶}$, Sukarddin ${ }^{2}$ \\ Institut Ilmu Sosial dan Ilmu Budaya Samawa Rea,Indonesia 1,2 \\ E-mail : Wahyuyayuk21@gmail.com ${ }^{1}$, sukarddinsejarah@gmail.com ${ }^{2}$
}

\begin{abstract}
Abstrak
Penelitian ini bertujaun untuk menggali informasi tentang problematika, harapan, dan memecahkan masalah yang dihadapi oleh dosen IISBUD SAREA dalam menerapkan pembelajaran daring di masa pandemi. Metode yang digunakan dalam penelitan ini adalah metode campuran (mix method) yaitu metode kualitatif dan kuantitif. Metode kualitatif dimaksudkan untuk menggali informasi tentang problematika dan harapan dosen dengan melibatkan wawancara, observasi dan dokumentasi, sedangkan metode kuantitaif dimaksudkan untuk memecahkan masalah dalam bentuk workshop atau pelatihan dengan melibatkan teknik pengumpulan data melalui kuisioner dan dokumentasi. Hasil penelitian menunjukkan bahwa terdapat berbagai macam masalah yang ditemukan yaitu masalah pengelaman dan kemampuan dosen dalam mengimplementasikan pembelajaran online yang masih sangat kurang, sarana yang tidak memadai, kesiapan dan kemampuan mahasiswa dalam mengikuti pembelajaran online masih sangat rendah, dan metode mengajar. Dari masalah tersebut kemudian dipecahkan dengan menyelenggarakan pengelolaan pembelajaran online berbasis moodlecloud. Ada 4 aspek yang dinilai dari pleatihan yaitu aspek kemenarikan yaitu 83,3\% atau sangat praktis, aspek biaya $89 \%$ atau sangat praktis, aspek waktu $80,4 \%$ atau praktis dan aspek kemudahan pengoperasian $93 \%$ atau sangat praktis. Selain itu, ada beberapa harapan yang dikemukakan oleh tenaga pengajar yaitu pelatihan harus disertakan dengan modul, waktu pelatihan perlu ditambah, perlu dilakukan pelatihan sejenis yang diperuntungkan untuk dosen dan mahasiswa.
\end{abstract}

Kata Kunci: Pembelajaran Online, Problematika, Pemecahan Masalah, Harapan.

\begin{abstract}
This study aims to dig up information about the problems, expectations, and solving problems faced by lecturers in implementing online learning during the pandemic. The method used in this research is a mixed-method. The qualitative method is intended to dig up information about the problems and expectations of lecturers by involving interviews, observation, and documentation, while the quantitative method is intended to solve problems in the form of workshops or training involving data collection techniques through questionnaires and documentation. The results showed that there were various kinds of problems found, namely the problem of experience and the ability of lecturers in implementing online learning which was still very lacking, inadequate facilities, readiness, and ability of students to participate in online learning was still very low, and teaching methods. This problem was then solved by organizing online learning management based on MoodleCloud. 4 aspects are assessed from the training, namely the attractiveness aspect, which is $83.3 \%$ or very practical, the cost aspect is $89 \%$ or very practical, the time aspect is $80.4 \%$ or practical and the ease of operation aspect is $93 \%$ or very practical. In addition, there are several expectations expressed by the lecturers, namely the training must be included with the module, the training time needs to be increased, it is necessary to conduct similar training that is beneficial for lecturers and students.
\end{abstract}

Keywords: Online Learning, Problems, Problem Solving, Expectatios.

Copyright (c) 2021 Sri Wahyu Hidayati, Sukarddin

$\triangle$ Corresponding author

Email : Wahyuyayuk21@gmail.com

DOI : https://doi.org/10.31004/edukatif.v3i6.1344

ISSN 2656-8063 (Media Cetak)

ISSN 2656-8071 (Media Online) 
4408 Pembelajaran Berbasis Daring pada Masa Pandemi Covid-19 di Iisbud Sarea: Problematika, Pemecahan Masalah, dan Harapan - Sri Wahyu Hidayati, Sukarddin

DOI: https://doi.org/10.31004/edukatif.v3i6.1344

\section{PENDAHULUAN}

Hadirnya pandemi covid-19 di Indonesia merubah pembelajaran mulai dari pendidikan dasar hingga perguruan tinggi secara luar biasa dari sistem pembelajaran luar jaringan (luring) menjadi sistem pembelajaran dalam jaringan (daring). Sejak terpaparnya covid-19 pada masyarakat di Indonesia, pemerintah melalui kementrian pendidikan dan kebudayaan (Kemdikbud) mengeluarkan surat edaran untuk melaksanakan pembelajaran online baik untuk perguruan tinggi yang berada di zona merah, kuning, maupun di zona hijau sebagai bentuk memutuskan mata rantai penyebaran covid-19. Melihat bahayanya penyebaran covid-19 dan menindaklanjuti surat edaran tersebut Institut Ilmu Sosial dan Ilmu Budaya Samawa Rea (IISBUD SAREA) mencoba menerapkan sistem pembelajaran online secara penuh. Namun, kondisi yang terjadi dilapangan bahwa pembelajaran online memiliki banyak persoalan yang dihadapi baik oleh mahasiswa maupun oleh dosen. Kondisi tersebut tidak dapat dibiarkan secara terus menerus karena akan mempengaruhi output lulusan dan berakibat pada lemahnya pengetahuan mahasiswa akan bidangmya. Oleh karena itu, diperlukan adanya inovasi dan kreativitas untuk merespon persoalan dalam proses pembelajaran sehigga dapat memberikan konstribusi untuk menunjang dalam pembelajaran online.

Melihat persoalan tersebut, beberapa penelitian revelan juga mendukung pernyataan penelitian yang akan dilakukan diantaranya adalah penelitian yang dilakukan oleh (Anwar et al., 2020;), (Syah, 2020), (Dwi et al., 2020), (Rahman, 2020), (Mustakim, 2020), dan (Khusniyah \& Hakim, 2019). Pada penelitian (Anwar et al., 2020) yang menfokuskan penelitianya pada pembelajaran online pada mahasiswa Fisk Iakn Ambon mengatakan bahwa pembelajaran online memiliki permasalah meskipun mereka sudah menggunakan pendekatan kearfian lokal yaitu Ale rasa beta rasa (belajar bersama). Penelitian ini tidak hanya dilakukan pada perguruan tinggi, namun juga pada orang tua mahasiswa untuk memberikan respon terhadap pembelajaran online. Jadi, penelitian ini berbeda dengan penelitian yang akan dilakukan dimana penelitian ini hanya mencoba menerapakan sistem pembelajaran bersama sebagai solusi alternatif dalam pembelajaran online namun tidak berhasil. Sementara penelitian yang akan dilakukan adalah menggali akar permasalahanya, mencarikan solusinya dan memecahkan masalahnya (problem solving) sehingga mahasiswa dan dosen memiliki kemampuan dalam menerapkan pembelajaran online, serta menggali harapan mahasiswa dan dosen serta pimpinan perguruan tinggi terhadap pembelajaran online. Kemudian, penelitian (Syah, 2020), (Dwi et al., 2020), (Syah, 2020), (Dwi et al., 2020), (Mustakim, 2020), (Khusniyah \& Hakim, 2019), (Kosim, Nanang, Imam Turmudi, Novy Maryani, 1995), (Setiawan et al., 2019), (Darmawan, Dwi Ariefin1, 2021), (Tafano \& Saputra, 2021), (Rohmanu et al., 2020), (Basar, 2021), dan (Anugrahana, 2020) juga memiliki problem yang sama baik pada psikologi siswa, kesiapan institut, maupun kemampuan mahasiswa dalam menerapkan pembelajaran online. Oleh karena itu, penelitian ini bertujuan untuk menggali problematika, mencarikan solusi dan memecahkan masalahnya (problem solving) untuk pembelajaran online yang efektif, dan juga menggali harapan mahasiswa, dosen dan pimpinan terhadap pembelajaran online. Selain memiliki tujuan yang jelas, penelitian ini memiliki urgensi yaitu problem solving terhadap pembelajaran online yang dihadapi oleh dosen di IISBUD SAREA.

\section{METODE PENELITIAN}

Penelitian pembelajaran berbasis daring pada masa pandemi covid-19 di iisbud sarea menggunakan metode campuran yaitu kualitatif dan kuantitatif. Pada teknik pengumpulan data kualitatif, penelitian ini melibatkan wawancara, observasi, dan dokumentasi. Sementara teknik pengumpulan data kuantitatif, penelitian ini menggunakan survei dengan memberikan kuisioner pasca pelatihan pada dosen. Pada tahap wawancara, peneliti telah mewawancar dosen-dosen Insitut Ilmu Sosial dan Ilmu Budaya Samawa Rea untuk menggali masalah yang dihadapi selama proses pembelajaran berbasis online. Kemudian pada tahap 
observasi, peneliti melakukan pengamatan langusng proses pembelajaran berbasis online yang dilakukan oleh dosen. Dan terakhir adalah dokumentasi, dokumentasi telah digunakan untuk mendapatkan informasi tambahan didalam bentuk tulisan-tulisan, arsip, dan dokumen lain yang dapat mendukung penelitian. Kemudian teknik pengumpulan data dengan menggunakan survei digunakan untuk memperoleh pendapat dosen tentang tingkat kepraktisan penggunaan MoodleCloud sebagai salah satu media yang dapat digunakan untuk mengajar secara daring. Teknik analisis data yang digunakan dalam penelitian ini juga terdapat dua pendekatan yaitu kualitatif dan kuantitatif. Untuk menganalisis data kuantitaif peneliti menggunakan langkahlangkah seperti yang dikemukakan oleh (matthew B. Miles, A. Michael Huberman, 2016) yaitu koleksi data, reduksi data, penyajian data, dan penarikan simpulan dan verifikasi. Sementara untuk mengalisis data survei adalah dengan menggunakan statistik. Instrument survei diberikan kepada dosen pasca mengikuti pelatihan moodlecloud untuk mengetahui tingkat keprakstisan penggunaan moodle dalam pembelajaran online yang terdiri dari sembilan (9) pernyataan dikelompokkan menjadi empat (4) aspek yaitu aspek kemenarikan, aspek biaya, aspek waktu, dan aspek kemudahan pengoperasian. Kuisioner diberikan dalam bentuk Google Form secara daring. Adapun kisi-kisi kuisioner adalah sebagai berikut:

Tabel 1. Kisi-kisi kuisioner Pendapat Dosen Pasca Pelatihan

\begin{tabular}{clc}
\hline No & \multicolumn{1}{c}{ Aspek } & Jumlah Item dan Nomor Item \\
\hline $\mathbf{1}$ & Kemanarikan & 3 item, item nomor 1-3 \\
\hline $\mathbf{2}$ & Biaya & 2 item, item nomor 4-5 \\
\hline $\mathbf{3}$ & Waktu & 2 item, item nomor 6-7 \\
\hline $\mathbf{4}$ & Kemudahan Pengoperasian & 2 item, item nomor 8-9 \\
\hline
\end{tabular}

Data pendapat dosen atau peserta pasca pelatihan kemudian dianalisis dengan menggunakan statistik deskriptif untuk melihat tingkat kepraktisan penggunaan moodlecloud apabila diterapkan dalam pembelajaran dalam jaringan. Kemudian, kuisioner untuk menguji tingkat kepraktisan menggunakan skala 1 sampai 5 dimana 1 = sangat tidak setuju, $2=$ tidak setuju, $3=$ netral, $4=$ setuju, dan $5=$ sangat setuju. Skor yang diperoleh dari kuisioner tersebut kemudian dianalisis dengan mengguanakn rumus dibawah ini;

$$
\text { index } \%=\frac{\text { total skor }}{\mathrm{Y}} \times 100
$$

Nilai tingkat Kepraktisan yang diperoleh kemudian disesuaikan dengan tabel kriteria tingkat kepraktisan dibawah ini:

Tabel 2. Kriteria Tingkat Kepraktisan

\begin{tabular}{ccc}
\hline Nilai & Interval & Kriteria \\
\hline 5 & $81-100$ & Sangat Praktis \\
\hline 4 & $61-80$ & Praktis \\
\hline 3 & $41-60$ & Cukup Praktis \\
\hline 2 & $21-40$ & Tidak Praktis \\
\hline 1 & $0-20$ & Sangat Tidak Praktis \\
\hline
\end{tabular}

Tabel diatas merupakan rujukan untuk mengetahui apakah moodlecloud dapat diterapkan dalam pembelajaran online khususnya di Institut Ilmu Sosial dan Ilmu Budaya Samawa Rea atau tidak.

\section{HASIL DAN PEMBAHASAN PENELITIAN}

Dalam penelitian ini terdapat tiga poin yang harus dijawab berdasarkan rumusan masalah penelitian yaitu pertama, promlematika pembelajaran online yang dihadapi oleh dosen Institut Ilmu Sosidal dan Ilmu 
4410 Pembelajaran Berbasis Daring pada Masa Pandemi Covid-19 di Iisbud Sarea: Problematika, Pemecahan Masalah, dan Harapan - Sri Wahyu Hidayati, Sukarddin

DOI: https://doi.org/10.31004/edukatif.v3i6.1344

Budaya Samawa Rea, kedua pemecahan masalah, dan terakhir harapan dosen terhadap pembelajaran online di Iisbud Sarea.

\section{Problematika}

Dalam proses pembelajan berbasis jaringan, berbagai macam problematika yang dihadapi baik oleh dosen pengampuh matakuliah maupun mahasiswa seperti: 1) pengalaman dan kemampuan dosen dalam pembelejaran online 2) sarana dan prasarana yang tidak mendukung, 3) kesiapan dan kemampuan mahasiswa dalam mengikuti pembelajaran online, 4) biaya yang harus dikeluarkan oleh dosen dan mahasiswa, dan 5) metode.

\section{Pengalamanan dan Kemampuan Dosen dalam Pembelajaran Online}

Berdasarkan hasil reduksi data dari hasil wawancara menunjukkan bahwa sebagian besar dosen Institut Ilmu Sosial dan Ilmu Budaya Samawa Rea masih sangat minim pengalaman dalam melakukan pembelajaran berbasis dalam jaringan. Selain itu, kemampuan dalam menggunakan teknologi dan media pembelajaran dalam jaringan juga sangat kurang sehingga sebagian besar dosen hanya menggunakan media whatsapp. Hanya sebagain kecil yang menggunakan google classroom dan zoom. Namun hal tersebut tidak hanya terjadi di Institut Ilmu Sosial dan Ilmu Budaya tetapi juga terjadi diberbagai daerah seperti yang dikemukan oleh (Ahmad Muzawir Saleh, 2020) yang mengatakan bahwa salah satu masalah yang timbul dalam proses pembelajaran berbasis jaringan adalah kekurangan akan pengalaman dalam menjalankan pemebalajaran daring dan keterbatasan pengalaman pengajar (Asmuni, 2020).

Dari media yang digunakan oleh dosen dalam melakukan pengajaran dalam jaringan tersebut sebagian besar mengatakan bahwa media whatsapp tidak efektif karena dosen hanya bisa memberikan materi dalam bentuk pdf tanpa memberikan vidio rekaman penjelasan tentang materi yang telah diberikan. Hal itu disebabkan karena kendala jaringan. Selain itu, dosen cukup merasa capet untuk mengetik penjelasan dalam whatsapp sehingga akhirnya dosen hanya bisa memberikan tugas.

\section{Sarana Pembelajaran}

Selain dari pengalaman dan kemampuan dosen dalam menyelenggarakan pembelajaran online, sarana dan prasarana juga merupakan salah satu yang menjadi masalah proses pembelajaran online tidak efektif seperti sebagian mahasiswa tidak memiliki leptop dan atau smarphone sebagai media untuk mengikuti proses perkuliahan dalam jaringan. Sarana pembelajaran mengambil peran penting dalam meningkatkan minat dan motivasi mahasiswa dalam mengikuti perkuliahan seperti juga dikatakan oleh (Ramadhani, 2013), (Apriani Kartika Sari , Muhsin, 2017), (Sudarwo, 2018), dan (Risa Santoso, 2021). Selain itu mahasiswa yang berada di daerah yang susah terjangkau oleh jaringan sangat jarang mengikuti perkuliahan sehingga mereka harus ke daerah yang terjangkau oleh jaringan untuk mengikuti perkuliahan secara daring. Hal tersebut sering kali menjadi keluahan sebagai besar mahasiswa karena rata-rata mahasiswa berasal dari daerah yang lumayan susah terjangkau oleh jaringan internet.

\section{Kesiapan dan Kemampuan Mahasiswa dalam Mengikuti Pembelajaran Online}

Masalah lain yang terjadi dalam proses pembelajaran online yang diselenggarakan di Institut Ilmu Sosial dan Ilmu Budaya adalah kesiapan dan kemampuan mahasiswa dalam mengikuti perkulaih berbasis dalam jaringan. Kesiapan dan kemampuan yang dimaksud dalam hal ini adalah kemampuan mahasiswa dalam menggunakan media pembelajaran dalam jaringan yang masih sangat kurang karena mereka tidak pernah menggunakan media pembelajaran online apapun sebelumnya. Artinya mahasiswa belum siap atau kemampuan mereka dalam menggunakan media untuk pembelajaran online masih rendah. Persoalanya ini tidak hanya berlaku di Institut Ilmu Sosial dan Ilmu Budaya Samawa Rea, namun ia juga berlaku di perguruan 
tinggi lain seperti hasil penelitian yang dilakukan oleh (Wardah et al., 2021). Selain itu, mereka tidak pernah diberikan pelatihan tentang bagaimana mengoperasi media pembelajaran online. Hal tersebutlah menyebabkan kemampuan merekan dalam menggunakan media pembelajaran online sangat rendah. Demi menjaga kelangsungan perkuliahan mahasiswa dan dosen dengan terpaksa menggunakan aplikasi WhatsApp sebagai media alternatif sehingga berefek pada hasil yang kurang memuaskan. Aplikasi WhatsApp sangat tidak efektif untuk digunakan dalam perkuliahan apalagi dibeberapa program studi mengharuskan perkualiahan tatap muka dan praktek.

\section{Metode Pengajaran}

Selain dari beberapa masalah yang ditemukan diatas, juga terdapat masalah lain yaitu metode pembelajaran yang diterapkan oleh dosen selama pembelajara online. Metode atau teknik yang diterapkan adalah metode pembelajaran berbasis tugas dimana tenaga pengajar memberikan materi dalam bentuk file lalu kemdian meminta mahasiswa mengerjakan tugas. Pemberian file materi tersebut dengan menggunakan media WhatsApp. Sebagian besar dosen yang memberikan materi dalam bentuk file tersebut tidak dibarengin dengan penjelasan. Artinya mahasiswa diminta untuk membaca dan memahaminya. Selain itu, beberapa dosen juga hanya meminta mahasiswa untuk meringkas buku teks yang menjadi pegangan dosen lalu kemudian dikumpulkan saat pertemuan terakhir. Metode atau teknik pembelajaran berbasis tugas tersebut pun mendapat kririkan dari berbagai mahasiswa karena mereasa bosan dengan teknik perkuliahan yang diselenggarakan. Namun, tidak dapat diingkari bahwa persoalan-persoalan tersebut merupakan dampak dari ketiaksiapan dosen dan mahasiswa dan kurangnya kemampuan dosen dalam menyelenggarakan pembelajaran berbabsis jaringan. Selain itu, rata-rata kemampuan tenaga pengajar cukup rendah dalam menggunakan berbagai media untuk pembelajaran online seperti Moodle Cloud dan lain-lain. Oleh karena itu, tenaga pengajar mengharapkan pelatihan-pelatihan yang mendukung penyelenggaraan pembelajaran berbasis jaringan sehingga ia terlaksana dengan efektif.

\section{Solusi Atau Probleb Solving}

Pada tahap ini peneliti mencoba memberikan solusi terhadap masalah-masalah yang telah ditemukan dan dideskripsikan diatas dengan menyelenggarakan pelatiahan atau workshop of Learning Management system dengan menggunakan moodlecloud. Moodlecloude merupakan salah satu media yang cukup menarik, praktis, dan menyenangkan untu digunakan dalam pembelajaran online (Effendi et al., 2019) dan (Husein, 2018).

Pelatihan ini diselenggarakan di Institut Ilmu Sosial dan Ilmu Budaya Samawa Rea dengan jumlah peserta 22 orang. Pelatihan yang diselenggarakan berjalan dengan cukup lancar sesuai dengan yang direncana meskipun terdapat beberapa kendala seperti waktu yang terbatas, salinan modul kurang cukup, dan lain sebagainya. Setelah pelatihan selesai para peserta diberikan sebuah quisioner untuk mengetahui tingkat kepraktisan moodlecloud sebagai salah satu media pembelajaran berbasis dalam jaringan (online). Hasil dari kuisioner tersebut, kemudian dianalisis seperti yang disajikan dalam tabel dan kurva berikut ini:

Tabel 3. Pendapat Dosen Pasca Pelatihan Penglolaan Pembelajaran Daring dengan Menggunakan Moodlecloud

\begin{tabular}{clccc}
\hline No & \multicolumn{1}{c}{ Aspek } & ¿Score & Perseentase(\%) & Kriteria \\
\hline $\mathbf{1}$ & Kemanarikan & 275 & 83,3 & Sangat Praktis \\
\hline $\mathbf{2}$ & Biaya & 196 & 89 & Sangat Praktis \\
\hline $\mathbf{3}$ & Waktu & 177 & 80,4 & Praktis \\
\hline $\mathbf{4}$ & Kemudahan Pengoperasian & 205 & 93,1 & Sangat Praktis \\
\hline
\end{tabular}




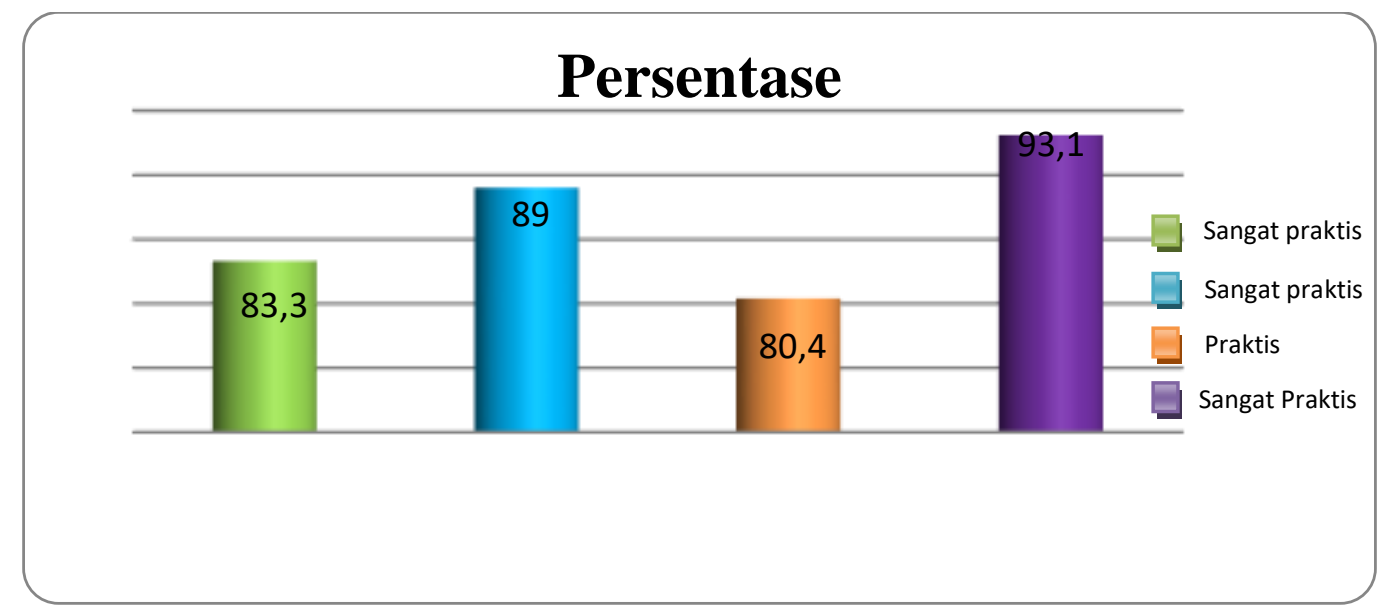

\section{Gambar 1. Kurva Pendapat Dosen Pasca Pelatihan Ditinjau dari Empat Aspek}

Dari tabel dan kurva diatas menunjukkan bahwa kemenarikan dari workshop moodlecluod adalah $83,3 \%$ sangat setuju atau dalam kategori sangat praktis dan dari segi biaya adalah $89 \%$ sangat setuju atau dalam kategori sangat praktis. Sementara dari segi waktu menunjukkan $80,4 \%$ adalah sangat setuju. Sedangkan kemudahan pengoperasian moodlecloud dalam sistem pembelajaran online menunjukkan 93\% sangat setuju atau dalam kategori sangat praktis. Dari jabaran diatas, aspek waktu tidak begitu tinggi dikarenakan waktu pembelajaran online berbasis moodlecloud tidak dapat memantau secara langsung sehingga hanya memantau kehadirannya dalam aplikasi tersebut. Namun dari keseluruhan bahwa ia berada dalam katgori praktis. Oleh karena itu, berdasarkan hasil analisis diatas bahwa moodlcloud merupakan salah satu media yang dapat digunakan dalam pembelajaran online baik dalam kondisi pandemic maupun pada dikondisi lain.

\section{Harapan}

Setelah diberikan pelatihan (coaching) tentang implementasi moodlecloud dalam pembelajaran online sebagai salah satu solusi dari masalah yang dihadapi dalam pembelajaran online di masa pandemik. Tenaga pengajara atau dosen-dosen juga memiliki berbagai harapan yaitu:

1. Pelatihan (Worskhop) ini diharapkan dilengkapi dengan dengang modul untuk membatu peserta dalam memahami hal-hal yang masih membingungkan, sebaiknya di sertakan dengan print out modulnya,

2. waktu workshop terlalu singkat dan perlu ditambah sehingga lebih banyak waktu untuk praktek,

3. workshop moodlecloud yang telah dilakukan perlu dilakukan lagi pada mahasiswa untuk memahami langkah-langkah kerja moodlecloud,

4. waktu pelatihan agar dapat lebih lama sehingga materi yang diterima peserta lebih banyak dan semakin mantap, dan

5. workshop sejenis ini perlu dilakukan agar dosen memiliki berbagai macam pengetahuan tentang perencangan pembelajaran dalam jaringan.

\section{KESIMPULAN}

Berdasarkan hasil temuan yang dideskripsikan diatas penelitian ini dapat disimpulkan bahwa terdapat berbagai macam masalah yang ditemukan selama implementasi pembelajaran online di masa pandemik khususnya di Institut Ilmu Sosial dan Ilmu Budaya Samawa Rea seperti masalah pengelaman dan kemampuan dosen dalam mengimplementasikan pembelajaran online yang masih sangat kurang, sarana yang tidak 

Masalah, dan Harapan - Sri Wahyu Hidayati, Sukarddin

DOI: https://doi.org/10.31004/edukatif.v3i6.1344

memadai, kesiapan dan kemampuan mahasiswa dalam mengikuti pembelajaran online masih sangat rendah, dan metode mengajar dosen yang sebagain besar menggunakan group whatsApp untuk membagi materi tanpa memberikan penjelasan sebagai pengantar. Dari berbagai macam masalah yang telah dikemukakan, peneliti memberikan sebuah pelatihan mengelola pembelajaran online berbasis moodlecloud. Pelatihan ini merupakan salah satu solusi atau problem solving untuk dosen yang memiliki kemampuan yang sangat rendah dalam mengelola pembelajaran online. Dari hasil pelatihan tersebut, ia dapat dikatakan bahwa pelatihan pengelolaan pembelajaran online berbasis moodlecloud cukup berhasil. Hal tersebut dibuktikan oleh pendapat dosen pasca mengikuti pelatihan yaitu pelatihan moodlecloud dari segi aspek kemenarikan adalah $83,3 \%$ atau berada dalam kategori sangat praktis. Sementaran dari segi biaya adalah $89 \%$ atau berada dalam kategori sangat praktis. Kemudian dari segi aspek waktu adalah $80,4 \%$ atau berada dalam kategori praktis dan aspek kemudahan pengoperasian moodlecloud adalah 93\% atau berada dalam kategori sangat praktis. Selain dari solusi yang diberikan, ada beberapa harapan yang dikemukakan oleh tenaga pengajar yaitu pelatihan harus disertakan dengan modul, waktu pelatihan perlu ditambah, perlu dilakukan pelatihan sejenis yang diperuntungkan baik untuk tenaga pengajara maupun untuk mahasiswa.

\section{UCAPAN TERIMA KASIH}

Ucapan terimakasih kami sampaikan kepada kepada pihak yang telah membantu baik berupa bantuan dana maupun berupa bantuan lain dalam menyelesaikan penelitian ini seperti DRPM, Kemdikbudristek, Lembaga Layanan Pendidikan Tinggi Wilayah 8 Bali-NTB serta dukungan dari Institut Ilmu Sosial dan Ilmu Budaya Samawa Rea karena Penelitian ini tidak akan selesai jika tidak bantuan dari pihak lain.

\section{DAFTAR PUSTAKA}

Ahmad Muzawir Saleh. (2020). Problematika Kebijakkan Pendidikan Di Tengah Pandemi Dan Dampaknya Terhadap Proses Pembelajaran Di Sekolah Dasar. Jurnal Qiroah, 10(2), 73-81. Https://Doi.Org/10.33511/Qiroah.V10n2.73-81

Anugrahana, A. (2020). Hambatan, Solusi Dan Harapan: Pembelajaran Daring Selama Masa Pandemi Covid19 Oleh Guru Sekolah Dasar. Scholaria: Jurnal Pendidikan Dan Kebudayaan, 10(3), 282-289. Https://Doi.Org/10.24246/J.Js.2020.V10.I3.P282-289

Anwar, A. A., Tuhuteru, A., Agama, I., \& Negeri, K. (2020). Ale Rasa Beta Rasa: Covid-19 Dan Pembelajaran Daring Mahasiswa FISK IAKN Ambon. Jurnal Emik, 3(1), 103-120.

Apriani Kartika Sari , Muhsin, F. R. (2017). Pengaruh Motivasi, Sarana Prasarana, Efikasi Diri, Dan Penyesuaian Diri Terhadap Kemandirian Belajar. Economic Education Analysis Journal, 6(3), 923-935.

Asmuni. (2020). Jurnal Paedagogy: Jurnal Paedagogy: Jurnal Paedagogy: Jurnal Penelitian Dan Pengembangan Pendidikan, 7(4), 281-288.

Basar, A. M. (2021). Problematika Pembelajaran Jarak Jauh Pada Masa Pandemi Covid-19. Edunesia : Jurnal Ilmiah Pendidikan, 2(1), 208-218. Https://Doi.Org/10.51276/Edu.V2i1.112

Darmawan, Dwi Ariefin1, I. P. A. (2021). Pemecahan Masalah Dalam Pembelajaran Melalui Kreativitas Guru Selama Masa Pandemi. PASCA: Jurnal Teologi Dan Pendidikan Agama Kristen, 17(1), 43-54. Https://Doi.Org/10.46494/Psc.V17i1.122

Dwi, B., Amelia, A., Hasanah, U., \& Putra, A. M. (2020). Analisis Keefektifan Pembelajaran Online Di Masa Pandemi Covid-19. Jurnal Pendidikan Guru Sekolah Dasar, 2(1), 28-37.

Effendi, H., Effendi, H., Irfan, D., \& ... (2019). Pendapat Guru Pasca Pelatihan Learning Management System Berbasis Video Menggunakan Moodlecloud. ... Jurnal Teknik Elektro Dan ..., 05(02), 52-58. 
4414 Pembelajaran Berbasis Daring pada Masa Pandemi Covid-19 di Iisbud Sarea: Problematika, Pemecahan Masalah, dan Harapan - Sri Wahyu Hidayati, Sukarddin

DOI: https://doi.org/10.31004/edukatif.v3i6.1344

Http://Ejournal.Unp.Ac.Id/Index.Php/Jtev/Article/View/106609

Husein, B. (2018). Pelatihan E-Learning Berbasis Moodle. Jurnal Off Character Education Society, 1(1), 5766.

Khusniyah, N. L., \& Hakim, L. (2019). Efektivitas Pembelajaran Berbasis Daring: Sebuah Bukti Pada Pembelajaran Bahasa Inggris. Jurnal Tatsqif, 17(1), 19-33. Https://Doi.Org/10.20414/Jtq.V17i1.667

Kosim, Nanang, Imam Turmudi, Novy Maryani, A. H. (1995). Pembelajaran Sejarah Melalui Daring; Problematika, Solusi, Dan Harapan. Journal Of Food System Research, 2(2), 54-65. Https://Doi.Org/10.5874/Jfsr.2.2_54

Matthew B. Miles, A. Michael Huberman, J. S. (2016). Qualitatif Data Analysis. Nursing Standard (Royal College Of Nursing (Great Britain) : 1987), 30(25), 33. Https://Doi.Org/10.7748/Ns.30.25.33.S40

Mustakim. (2020). Efektivitas Pembelajaran Daring Menggunakan Media Online Selama Pandemi Covid-19 Pada Mata Pelajaran Matematika The Effectiveness Of E-Learning Using Online Media During The Covid-19 Pandemic In Mathematics. Al Asma: Journal Of Islamic Education, 2(1), 1-12.

Rahman, T. (2020). Pembelajaran Daring Di Era Covid-19. Osteoarthritis And Cartilage, 28(2), 1-7. Http://Journals.Sagepub.Com/Doi/10.1177/1120700020921110\%0Ahttps://Doi.Org/10.1016/J.Reuma.20 18.06.001\%0Ahttps://Doi.Org/10.1016/J.Arth.2018.03.044\%0Ahttps://Reader.Elsevier.Com/Reader/Sd/ Pii/S1063458420300078?Token=C039B8B13922A2079230DC9AF11A333E295FCD8

RAMADHANI, R. (2013). Pengaruh Sarana Pembelajaran Dan Motivasi Belajar Terhadap Kemandirian Belajar Mahasiswa Pada Mata Kuliah Komputer Program Studi Pendidikan Administrasi Perkantoran Fakultas Ekonomi Universitas Negeri Yogyakarta. International Migration Review, 47(2), 330-373. Http://Onlinelibrary.Wiley.Com/Doi/10.1111/Imre.12028/Abstract

Risa Santoso. (2021). Pengaruh Motivasi Dan Sarana Belajar Online Terhadap Kemandirian Belajarmahasiswa Di Masa Pandemi Covid-19. Jurnal Pendidikan Ekonomi, 14(2579-3780), 25-36. Http://Journal2.Um.Ac.Id/Index.Php/Jpe/Index

Rohmanu, A., Muafiah, E., Rahman Hakim, A., \& W Damayanti, V. V. (2020). Kesiapan, Kompleksitas Dan Harapan Pembelajaran Jarak Jauh: Perspektif Mahasiswa Iain Ponorogo. Al-Tadzkiyyah: Jurnal Pendidikan Islam, 11(2), 221-241. Http://103.88.229.8/Index.Php/Tadzkiyyah/Article/View/7019

Setiawan, A. R., Puspaningrum, M., \& Umam, K. (2019). Pembelajaran Fiqh Mu'Āmalāt Berorientasi Literasi Finansial. TARBAWY: Indonesian Journal Of Islamic Education, 6(2), 187-192. Https://Doi.Org/10.17509/T.V6i2.20887

Sudarwo, R. (2018). Influence Of Learning Facilities And Student ( Empirical Study On Bidikmisi Scholarship Students Regional Office Of Universitas Terbuka At Ternate ) Terhadap Kemandirian Belajar Mahasiswa ( Studi Empiris Pada Mahasiswa Beasiswa Bidikmisi UPBJJ-UT Ternate. Jurnal Pendidikan, 19(2), 69.

Syah, R. H. (2020). Dampak Covid-19 Pada Pendidikan Di Indonesia: Sekolah, Keterampilan, Dan Proses Pembelajaran. SALAM: Jurnal Sosial Dan Budaya Syar-I, 7(5). Https://Doi.Org/10.15408/Sjsbs.V7i5.15314

Tafano, T., \& Saputra, S. (2021). Teknologi Dan Covid: Tantangan Dan Peluang Dalam Melaksanakan Pembelajaran Daring Di Masa Pandemi. Djtechno Jurnal Teknologi Informasi, 2(1), 45-53. Https://Doi.Org/10.46576/Djtechno.V2i1.1256

Wardah, D., Rohmah, M., Dhika, M., \& Rizqan, A. (2021). Kesiapan Mahasiswa Dalam Pembelajaran Daring Dan Hubungannya Dengan Hasil Belajar Kata Kunci Abstrak Kata Kunci Abstrak Pelaksanaan EKBM Tentunya Memberi Dampak Yang Signifikan Bagi Mahasiswa Ba- Dan Belajar Mandiri . Namun , Seiring Berjalannya Masa Stud. 136-147. Https://Doi.Org/10.23917/Humaniora.V22i2.9460 